\title{
Cities and Global Governance: State Failure or a New Global Order? ${ }^{1}$
}

For Failure and Denial in World Politics: Millennium, Special Issue 2016, 44.3

Keywords:

Global Cities, Global Order, Global Governance, International Society

\begin{abstract}
International society, so long the resolution to problems of collective political order, now appears to be failing in its capacity to deal with transnational challenges such as climate change, global security and financial instability. Indeed, the structure of international society itself has become a significant obstacle to such pressing issues of global governance. One striking response has been the reemergence of cities as important actors on the international stage in recent decades. This article will show how these two issues are intrinsically linked. Cities have taken on new governance roles in the gaps left by hamstrung nation-states, and their contribution to an emerging global governance architecture will be a significant feature of the international relations of the twenty-first century. But do the new governance activities of cities represent a failure on the part of states, as some scholars have argued? Or are they a part of an emerging form of global order, in which the relationship between states, cities and other actors is being recalibrated? This article argues that the remarkable renaissance of cities in recent decades has been a result of a shift in the structure of international society, and assesses the causal drivers of this shift. It goes on to draw out some of the implications of the recalibration of the relationship between the city and the state for how we understand the emerging form of global order.
\end{abstract}

\section{Introduction}

The political theorist Benjamin Barber recently made an eye catching call for a global 'parliament of mayors'. ${ }^{2}$ His argument was that the failure of the state (and of the wider society of states) to make successful inroads into serious transnational governance issues, such as climate change, called forth a pressing need for alternative global governance arrangements. At the same time he argued that states have become ever more distant from their citizens, who are increasingly alienated by a widening democratic deficit. For Barber it is in the renaissance of urban life that solutions to these dual crises of the nation-state can be found. He wants to see new scale-jumping municipal democratic bodies emerge, harnessing technological advances to join up local participation with novel transnational urban assemblies. And, although calls for the establishment of a global parliament of mayors may

\footnotetext{
${ }^{1}$ Simon Curtis is a Lecturer in International Politics at the University of East Anglia, and a Senior Fellow on Global Cities at the Chicago Council on Global Affairs. He is the author of The Power of Cities in International Relations (2014, Routledge) and Reassembling International Theory (2014, Palgrave) with Michele Acuto. His next book, Global Cities and Global Order, will be published by Oxford University Press in 2016, and examines the importance of global cities in the transformation of world order.

${ }^{2}$ Benjamin Barber, If Mayors Ruled the World : Dysfunctional Nations, Rising Cities (London: Yale University Press, 2014).
} 
sound radical, Barber claims that it would be, in effect, merely a formalization of wellestablished political trends.

A networked form of city led global governance is not, for Barber, a utopian blueprint, but simply the identification and amplification of existing trajectories and concrete practices. The capacities for such governance roles already exist in the various global city networks that have been constructed. Voluntary and informal co-operation already occur across the many city networks that have been built - of which the C40 Climate Leadership Group, Metropolis, the International Council for Local Environmental Initiatives (ICLEI), Mayors for Peace, Sister Cities International, United Cities and Local Government (UCLG), or the European Forum for Urban Security (EFUS), are but the tip of a huge iceberg. A project is currently underway at University College London to map and assess the nature of contemporary city networks and their growing diplomatic connections. Initial estimates suggest there may be over two hundred such city networks, of various types. ${ }^{3}$

It is clear, then, that we already inhabit a 'decentralized planet of networked cities, provinces and regions [which] while obviously dominated by traditional nation-states...encompasses a wide variety of sub-state and non-state actors, from multi-national corporations and global financial institutions to civic NGOs and global social movements'. ${ }^{4}$ These networks have grown in the spaces and gaps left by the states governance failures. However, what is critical to note - and this is a point that Barber leaves unmade - is that such transnational urban networks are not simply a challenge to the state. This is not a zero-sum game, where the rise of cities necessarily means the decline of states. The rise of the city should not be seen as a symptom of the exhaustion of the state as a political form, but, rather, a facet of the adaptation of the state as it tries to cope with a changing environment. In this sense, it is not the state that is failing, but a particular historical iteration of the state - the nation-state - that is being reassembled into a new form. It is not international society that is failing, but a historically specific form of international society, which is now evolving in an attempt to transcend its limitations. And a new historically distinctive form of the city - the Global City - has become a critical component of the devolved governance strategy of leading liberal states at the contemporary conjuncture. Such cities are, then, a facet of a historically specific form of world order.

This is an emerging order full of contradictions and unresolved dilemmas. The empowerment of cities is necessary for them to fulfil their crucial roles in a devolved governance regime. Yet, despite having created the conditions in which certain cities have thrived, states still

\footnotetext{
${ }^{3}$ The City Leadership Initiative is a partnership between University College London, World Bank and UN-Habitat: http://cityleadership.net

${ }^{4}$ Barber, If Mayors Ruled the World, 302

${ }^{5}$ Here I use the term 'global city' to denote a historically specific form of city morphology that is linked to globalisation. It should be noted that some scholars have argued that global cities, or world cities, have always been a feature of historical international systems. While space does not permit discussion of these debates, my usage of the term follows Sassen in that it denotes the changes wrought to the urban fabric by the restructuring of the world economy in the 1970s. This is the position taken by much of the global cities literature as it emerged in the fields of urban studies and political geography. As Peter Taylor remarks in World City Network: A Global Urban Analysis (London: Routledge, 2003, 21): 'the world city literature as a cumulative and collective enterprise begins only when the economic restructuring of the world economy makes the idea of a mosaic of separate urban systems appear anachronistic and irrelevant.' Here, the world or global city becomes the spatial expression of a new form of global capitalism, and thus marks a distinctively late-modern development. In this article I also add to this discussion by focusing more carefully on the role of both US power and liberal norms in the emergence of global cities than has heretofore been the case within these disciplines.
} 
retain an ambivalent relationship with the new global cities that their own policies have generated. Nowhere is this ambivalence more apparent than in the run up to UN-HABITAT III, taking place in Quito, Ecuador in October 2016. States have commissioned UNHABITAT to outline a twenty-year strategy for sustainable, equitable and socially just urban development. On the one hand, the central role ascribed to cities in driving such initiatives is an acknowledgement by states that cities are the only administrative entities that can put these aspirations for sustainable development into practice: this is, after all, a 'new urban agenda'. On the other hand, it is striking that the leadership of cities was not even consulted in the preparatory conferences running up to the main event. As the Mayor of Berlin, Michael Muller, complains: 'countries are largely agreeing on preparatory work [for Habitat III] without the contribution of cities, even though it is the future of cities that is in question. This is absurd'. ${ }^{6}$ Until Metropolis forced the issue, and gained urban representation at these sessions, cities and their leaders were not even part of the formal discussions on the new urban future.

States retain a residual reluctance to let go of control. In a sense, they are in denial about the emerging form of global order that they have created. And yet, letting go is likely to be the only way in which the desired outcomes can be achieved within the governance frameworks that states have themselves helped to construct. States seem to realise that they must empower cities to take a seat at the top table - the complexity of global governance issues demands that. Yet, perhaps states fear where this may lead - the reflexes of centuries of sovereignty are hard to retrain. In the longer term, possible serious tensions between cities (growing in authority, power and legitimacy) and states (the traditional possessor of these qualities) cannot be ruled out. But in the present moment, the rise of the city also reflects a transformation in the nature of the state itself, and of the wider international society of which each state is a part. The concern of this article is to show just how and why cities have become so significant to an emerging form of global order whose very existence signals the reality of profound international change.

The problem for International Relations (IR) scholars is that the shape of the historiography of the discipline has made it difficult to even see these types of developments, let alone theorise them adequately. ${ }^{7}$ Cities have long been viewed as sub-national political entities, internalized within the territorial boundaries of their host state, and therefore located at a different level of analysis to those that concern much mainstream IR scholarship. There is a very marginal literature on the paradiplomacy of cities, while Chadwick Alger's work on the role of cities in the UN system has been a significant contribution. ${ }^{8}$ But, in general, cities have been deemed relatively unimportant. However, the growing appreciation of very significant changes to the urban fabric over the past in few decades - particularly its transnational character - is beginning to reverse this neglect.

The immense growth of urban settlements is a core feature of the twenty-first century. The

\footnotetext{
${ }^{6}$ Michael Muller, "Cities Must Be Part of Defining the New Urban Agenda," Citiscope 2015.

${ }^{7}$ Simon Curtis 'Global Cities and the Transformation of the International System' Review of International Studies 37, no. 4: (2010):: 1923-1947

${ }^{8}$ Francisco Aldecoa, and Michael Keating, Paradiplomacy in Action: The Foreign Relations of Subnational Governments (London ; F. Cass, 1999); Andre Lecours, "Paradiplomacy: Refelctions on the Foreign Policy and International Relations of Regions," International Negotiations, 7, no.(2002): 119-125; Leo Van Der Pluijm, and Peter M.J Pol, "City Diplomacy: The Expanding Role of Cities in International Politics," Clingendael Diplomacy Papers, (2007); David Criekmans, "Regional Sub-State Diplomacy from a Comparative Perspective: Quebec, Scotland, Bavaria, Catalonia, Wallonia and Flanders," The Hague Journal of Diplomacy, 5, no. 1/2 (2010),: 37-64; Chadwick Alger, "Searching for Democratic Potential in Emerging Global Governance," International journal of Peace Studies, 16, no. 2 (2011): 1-24.
} 
rural world of yesterday has disappeared, as populations have either been drawn from the land to seek the opportunities that only city life can offer, or pushed out from traditional agricultural occupations by a combination of technological advance and structural adjustment programmes. Concentrated into just $2 \%$ of the world's surface, the great urban hubs now hold over half of the world's population, and it is estimated that by 2050 over $66 \%$ of the world's population will live in cities. ${ }^{9}$ UN-HABITAT has documented how the number of cities in the world with populations greater than 1 million increased from 75 in 1950 to 447 in $2011 .^{10}$ In the decade between 1990 and 2000 alone there was a $30 \%$ increase in the size of urban settlements in the developed world and a 50\% increase in the developing world.

As expanding cities merge into each other, they have generated vast conurbations that stretch across multiple national territories. Contemporary urban forms are unlike any in the historical record - stretching skyward in the immense verticality of the central business district, unfurling horizontally, spurred on by new information and transport technologies to cannibalise the national space, and often to break through its bounds to form distinctive transnational urban regions that tie stretches of global space together in novel ways. ${ }^{11}$ Such cities also exhibit marked polarization, and have generated huge informal settlements and slums that are as much a part of the new global city as the relatively tiny, yet globally connected, throbbing technological hub of the central business districts. Advances in information and communications technologies have given city networks global reach and augmented the centrality and power of an exclusive set of nodal points. The construction of the global digital infrastructure, in combination with the stitching together of supra-territorial urban regions via transport technologies such as high speed rail links and air-traffic routes, offers a twenty first-century transnational equivalent of the ways in which networks of canals and roads integrated the territorial space of nation-states in earlier centuries. The global city network is the material exoskeleton of globalisation, and its nodes the command hubs for the governance of many kinds of global flows. ${ }^{12}$ Indeed, the construction of this planetary urban infrastructure represents the emergence of a 'large technical system' that in itself may be seen to indicate a shift in international order. ${ }^{13}$

Such cities are being shaped by exposure to the logics of market forces, tapping into and redirecting flows of global capital, drawing their development from streams of financial speculation in real estate and infrastructure projects. In this sense the transformation of the city fabric has been driven by the far reaching neoliberal restructuring of the global economy that began in the 1970s, and the subsequent period of accelerated globalisation. Transformed by the project of leading states to build a global market society, cities have been swollen by the full force of the unique agglomeration economies that they foster. Over $80 \%$ of global economic output is generated by contemporary cities. They are the points at which productivity, innovation, and wealth converge)..$^{14}$

${ }^{9}$ UN Department of Economic and Social and Affairs, "World's population increasingly urban with more than half living in urban areas", July 2014.

${ }^{10}$ UN-Habitat, State of the World's Cities 2008/2009: Harmonious Cities (London: Earthscan, 2008).

${ }^{11}$ Allen Scott, Global City-Regions : Trends, Theory, Policy (New York: Oxford University Press, 2000).

${ }^{12}$ John Friedmann, "The World City Hypothesis," Development and Change, Vol. 17 (1986), 69-83; Saskia Sassen, The Global City : New York, London, Tokyo (Princeton: Princeton University Press, 1991); Saskia Sassen, Territory, Authority, Rights : From Medieval to Global Assemblages (Princeton: Princeton University Press, 2006a);

${ }^{13}$ Michele Acuto, and Maximillian Mayer, "The Global Governance of Large Technical Systems," Millennium, 43, no. 2 (2014): 660-683; Neil Brenner, and Christian Schmid, "Planetary Urbanisation," in Matthew Gandy, ed., Urban Constellations (Berlin: Jovis, 2011).

${ }^{14}$ Mario Polèse, The Wealth and Poverty of Regions : Why Cities Matter (Chicago, Ill. ; London: University of Chicago Press, 2011); Edward. Glaeser, Triumph of the City (London: 
Changes to the material form of cities over the last four decades have been extensively studied by scholars working in fields such as Urban Studies and Political Geography. This 'invisible college ${ }^{15}$ of scholars has done much to help us to come to terms with the dynamics of urban transformation, developing theoretical frameworks and empirical data. However, this literature is strikingly devoid of a broad geo-political and geo-historical perspective, which IR scholars should be well placed to provide. As IR scholars have belatedly recognised these trends, we have moved in recent years from a situation in which cities were barely discussed at all in IR (notable exceptions are to be found in the world-systems literature, ${ }^{16}$ to a steady increase in the number of articles and book length scholarly treatments of the global city phenomenon within an IR context. ${ }^{17}$

IR scholars have been particularly well placed to reveal the lack of political analysis in the global cities literature. The early work of scholars in the global city tradition had focussed primarily on the economic attributes of such cities. ${ }^{18}$ The IR contribution has so far considered the role of cities in environmental global governance, the increasing importance of city mayors as international actors, the role of cities as regional hubs, the connection of cities to the historical development of the international system, and the uneven relative power of certain cities and the origins of such power. ${ }^{19}$ However, my contention would be that there has to date (even in scholarship coming from an IR perspective) been an inadequate appreciation of why the global city emerged at the point in history that it did, and in the distinctive morphological form that it did. Even Sassen is content to link this urban form to globalisation, while failing to probe further the underlying form of international society that underpins and enables it. Economic functionalism, although clearly part of the story, is an inadequate explanation for how the political conditions of possibility for such cities were generated. It is also a weak guide to the very profound political implications of the emergence of global cities.

What I want to demonstrate in this article is that it is not simply a widening of the field of vision that is required here, but an appreciation that the very emergence of the 'global city' (whether we interpret it as a conceptual device or heuristic, as a material entity, as a political actor, as a discourse) tells us something very important about international political order at the contemporary conjuncture. Such cities are both an indicator of and a result of a deep shift in the nature of international society. The consequences of this must be wide-ranging; for the form of political order that international society has provided has underpinned international life throughout the modern period. Once we appreciate this, a whole set of questions open up that are vital to the more mainstream agenda of scholars of world politics; questions of state transformation, the nature of global governance architecture, international security and the character of international political order. IR scholars should be taking note of these urban

Macmillan, 2011); Jane Jacobs, Cities and the Wealth of Nations : Principles of Economic Life (New York: Random House, 1984);

${ }^{15}$ For a summary, see: Michele Acuto, "Finding the Global City: An Analytical Journey through the 'Invisible College'," Urban Studies,. 48, no. 14 (2011): 2953-2973.

${ }^{16}$ Christopher K. Chase-Dunn, and Thomas D. Hall, Rise and Demise : Comparing WorldSystems (Boulder: Westview Press, 1997).

${ }^{17}$ Simon Curtis, ed. The Power of Cities in International Relations (New York: Routledge, 2014); Mark Amen, ed. Cities and Global Governance : New Sites for International Relations (Farnham: Ashgate, 2011). Mark Amen, Kevin Archer, and Martin Bosman, eds. Relocating Global Cities: From the Center to the Margins (Oxford: Rowman \& Littlefield, 2006).

${ }^{18}$ Mark Amen, et al, eds. Relocating Global Cities

${ }^{19}$ Sofie Bouteligier, Cities, Networks, and Global Environmental Governance : Spaces of Innovation, Places of Leadership (New York: Routledge, 2013); Michele Acuto, Global Cities, Governance and Diplomacy : The Urban Link (Abingdon, Oxon. ; New York, NY: Routledge, 2013). 
developments, and asking: what are the political conditions of possibility that allow for such a fragile network of global cities to emerge, and to endure, in a world where security has been the preserve of the state, and cities have long ago lost their pre-modern defensive capabilities? What does the emergence of the global city tell us about the changing nature of the state, and of state sovereignty, territoriality and bordering practices in the early twenty-first century? What forms of identity emerge within the political spaces of global cities, and how far might they challenge a modern subjectivity and sense of citizenship constructed around the nation? What does the rescaling of the city - and the state - tell us about the ongoing tensions between an international system built upon the foundation of territorial sovereignty, and a fundamentally transnational capitalist economic system? These are issues that will feature in the following discussion. There is a vast and under-explored research programme here, and one function of this article is to try to make visible its outlines.

The article proceeds in three sections. Each section delves progressively deeper into the issues indicated by the shift in urban morphology and city practices. The first section looks at the role that cities have been playing in an emerging, decentered, global governance architecture. The second seeks to explain how and why this architecture developed, and why cities are a critical component of it. The third section then seeks to unravel some of the political implications of these developments. It argues that the evolution of international political order, towards a nascent form of global order, augers a period of transition for states, cities and international society alike, and examines some of the consequences of this transition at the contemporary conjuncture. In particular, this final section of the article warns that, even though an urban renaissance may be necessary to deal with problems of a transnational scope, it represents a disruption to core ordering principles such as sovereignty and territoriality. It therefore brings in its wake the risk of reopening many of the problems of political order that the modern international system emerged to resolve. In this sense, cities are likely to be central spaces in which systemic contradictions and distortions will be played out in the twenty-first century, and in which novel forms of political, social and economic practices will emerge.

\section{Decentering Governance: Towards Global Order}

As Barber's recent intervention makes clear, cities take their place in an emerging global governance regime that has unfurled gradually over recent decades. The global governance features of global cities may be seen as a facet of an emerging global order, imperfectly worked out and feeling its way into the twenty-first century. Such an emerging global order may be seen as a historically specific iteration of international political order, and rests upon the bedrock of the international society of states, which provides it with its conditions of possibility.

The concept of international order lies at the core of international theory. Differing interpretations of the character of this order continue to divide the discipline. There is a tension between those that view international political order as a set of stable and regular patterns of behaviour (for example, the school of structural realism, which concerns itself primarily with recurrent patterns of power balancing between states across the span of history), and those that view order in a more normative and less mechanical sense, stressing the evolution of norms, rules and values. Hedley Bull argued that the common rules and institutions developed by states over time constituted not just a system of interaction, but an international society. ${ }^{20}$ It is this understanding of international order that allows insight into how states might collectively develop new norms that can fundamentally alter the

\footnotetext{
${ }^{20}$ Hedley Bull, The Anarchical Society : A Study of Order in World Politics (London: Macmillan, 1977)
} 
environment in which they operate. ${ }^{21}$ I want to show here how the historical evolution of the dominant norms in international society, specifically the centrality of liberal ideas, backed by a particular configuration of material power, has begun to reshape international society in interesting ways, changing the nature of the state itself, as well as its relation to other entities and actors, including cities previously internalised within the national polity.

In this sense, the emergence of both global cities and global governance is a result of the distinctive path taken by the international society of states in the latter part of the twentiethcentury. For much of the modern period the values or goals of international society aimed at little more than coexistence; the norms of political sovereignty and non-intervention, for example, were directed towards the guarantee of political independence for states, and the regulation of the conduct of conflict and warfare between them. The key value of this form of political order was the survival of international society itself.

Although this type of minimal - or pluralist - international society seemed especially valuable in the Cold War context in which Bull wrote, the character of political order has undergone an important shift since the mid-twentieth-century. The narrow focus of a pluralist international society on issues such as war, peace and diplomacy has begun to give way to a more extensive complex interdependence aimed at regulating an increasingly complex global economy, and dealing with transnational issues such as climate change, or the management of volatile global markets, or the emergence of transnational forms of criminal activity and security threats.

The issue of how a traditional sovereignty based order might come to regulate the transnational forces and transnational spaces that are a feature of the current conjuncture becomes a key problem of our time. This mismatch between the transnational scale of such problems and the resources of international society to deal with them seems to indicate a functional requirement for such problems to be devolved to other actors who do have the scope to make an impact. It is here that new practices of global governance are emerging and it is this requirement that scale-jumping cities are well placed to fill. In this sense, global cities may be seen as part of an emerging global order generated by a shift in the normative structure of international society.

Cities are thus able to take their place among a range of other actors in a nascent global governance architecture. Such a global order has been constructed on the foundations of an increasingly solidarist liberal international society. But it is also clear to English School thinkers that the nascent global order contains many points of tension and contradiction with that earlier pluralist form of international order. ${ }^{22}$ This has, of course, long been the contention of globalisation theorists, particularly the more sophisticated 'transformationalist' variant. ${ }^{23}$ But this question of order transition needs a more sophisticated and nuanced interpretation than much of the globalisation literature offers. Rather than a simple transition from the national to the global scale, we seem to be seeing the emergence of complex multinodal and multi-scalar forms of governance, where the emerging links between different actors are 'crystallising into transnational webs of power', and states are increasingly becoming enmeshed in these webs (Cerny 2010, 4). ${ }^{24}$

\footnotetext{
${ }^{21}$ Curtis 'Global Cities and the Transformation of the International System'.

${ }^{22}$ Barry Buzan, From International to World Society? : English School Theory and the Social Structure of Globalisation (Cambridge: Cambridge University Press, 2004); Andrew Hurrell, On Global Order : Power, Values, and the Constitution of International Society (Oxford: Oxford University Press, 2007).

${ }^{23}$ Nick Bisley, Rethinking Globalization (New York: Palgrave Macmillan, 2007).

${ }^{24}$ Philip Cerny, Rethinking World Politics : A Theory of Transnational Neopluralism (New York ; Oxford: Oxford University Press, 2010), 4
} 
Global governance, then, offers a compromise; a mid-point on the spectrum of order, somewhere between the pluralist anarchical international society and world government. It involves the empowerment of many actors above and below the state, including the individuals, social movements, NGOs and institutions that comprise civil society. It involves a fusion or recalibration of public and private actors, coming together in hybrid functional networks to find solutions to problems of collective action where states have been wanting. These are forms of interaction that are horizontal, non-hierarchical, and embrace the bottomup dynamics of self-organisation. The normative proposition is that they bypass vertical, hierarchical and centralised (statist) structures where power has so often ossified in the history of the twenty-first century. This derives from a set of liberal philosophical principles, particularly those of market exchange and mutuality. It lays emphasis upon an expansion of private authority in complex governance and the provision of public goods - whether this manifests itself in private legal systems such as commercial arbitration, or the use of technical knowledge, such as in the work of credit ratings agencies. ${ }^{25}$ This emerging system is no longer effectively captured by either the anarchical or hierarchical categories of international structure, but represents instead a form of heterarchy - a system in which political authority and governance are shared among a variety of actors. ${ }^{26}$

In delegating state authority to a range of other actors, via its fusion of public and private governance, this form of global order is inherently decentralising. The importance of contemporary cities to this global governance system lies not just in their proximity to the local, nor in their transnational reach, but also in the way that they have developed capabilities to tie these scales together to generate the capacity for novel forms of governance. The growing network of 83 major cities represented by the C40 Climate Leadership Group offers a greater scalar reach than any state can achieve. There is a growing literature on global governance in IR that stresses the hybrid nature of transnational governance ${ }^{27}$ Many of the same drivers that have allowed actors such as international NGOs to take up an important role in such arrangements are also applicable to the rise of cities. In this sense, the global city is revealed as part of an emergent hybrid global order, in which the primacy of the state appears to have been either eroded or abdicated, and new practices are developing. As cities have increasingly become a core feature of this governance regime, they have made forays into influencing global governance outcomes, and they have begun to exhibit capacities that might lead us to think that, as Barber clearly does, they will play an ever greater role in future governance arrangements. Today, we see the emerging governance capacities of cities in multiple spheres. Novel developments in scale-jumping city governance can be seen across the political, security and economic domains.

In the political domain one notable feature of changing urban governance, and one that contains significant implications for the future of global governance, is the rise to prominence of the city mayor ${ }^{28}$ Charismatic global city mayors such as Michael Bloomberg in New York, or Boris Johnston in London, have enjoyed a rising profile in recent years. But beyond their media presence, the very phenomena of the city mayor, as well as the increasing devolution of governance functions and powers to cities, reveals a trend towards a reinvigoration of urban politics and a recalibration of state authority. British Chancellor George Osborne's

25 Mathias Koenig-Archibugi, and Kate Macdonald, "Accountability-by-Proxy in Transnational Non-State Governance," Governance, 26, no. 3 (2013): 499-52

${ }^{26}$ Jack Donnelly, "Rethinking Political Structures: From 'Ordering Principles' to 'Vertical Differentiation' - and Beyond," International Theory, 1, no. 1 (2009)

${ }^{27}$ Thomas Weiss, and Rorden Wilkinson, "Global Governance to the Rescue" Saving International Relations," Global Governance, 2014, 20, no. 1 (2014): 19-36; Oran Young, Governance in World Affairs (Ithaca, NY: Cornell University Press, 1999); Joseph Nye, and John D. Donahue, Governance in a Globalizing World (Washington, D.C.: Brookings Institution Press, 2000).

${ }^{28}$ Acuto, Global Cities, Governance and Diplomacy; Barber, If Mayors Ruled the World 
shortly to be introduced Cities Devolution Bill - in which 'Northern Powerhouse' English city regions will gain greater control over health, social care, policing, planning and municipal tax revenues - is but one manifestation of this broader decentralizing trend.$^{29}$

These trends are not restricted to powerful Western cities. Barber highlights the impact of Delhi Mayor Sheila Dikshit, whose innovative programme of town hall meetings and participatory budgeting has successfully involved citizens directly in the governance of their city. ${ }^{30}$ This is part of a notable global trend in recent decades that has seen many experiments in participatory budgeting, with citizens playing a role in the allocation of a portion of the city budget. ${ }^{31}$ In fact the participatory budgeting experiment that began in the 1980s in Latin America has spread around the world, including to cities in North America and Europe. There are now over three thousand cities that have experimented with some form of participatory budgeting. And, although such practices have operated at a very small scale, representing a tiny proportion of the overall city budget, nevertheless they instantiate a model of good governance practice, and offer a pathway to greater civic participation.

Mayors have also played key roles in pushing cities and local governments to develop capabilities as networked actors that allow them to have the global reach that they need to bridge the various scales at which the global issues that effect them operate. The new technical capacities offered by digital networks have meant that it is increasingly possible for mayors to straddle the local and the global scales. Mayors for Peace, with over 5000 city members in 153 states, comprises a cooperative network of cities that strive to place the abolition of nuclear weapons on the international agenda, as well as issues surrounding poverty and refugees, local conflicts and environmental change. Metropolis, or The World Association of Major Metropolises, has been around since 1985 and has over 100 members, offering a forum for sharing knowledge and best practices that promote urban sustainability. The World Organisation of United Cities and Local Governments represents a recent attempt to boost the political representation of local government in the international arena, in particular with the United Nation's agencies that deal with urban issues, such as UNESCO, UN-HABITAT and the World Bank.

Perhaps the most fully developed network is the C40 Climate Leadership Group, whose city members engage in strategic partnerships with private actors such as the Clinton Foundation's Climate Change Initiative and multi-national engineering corporations such as Arup. The C40 group seeks to lead efforts to tackle climate change, recognising that cities already have the potential resources to contribute to positive governance outcomes on the global stage. These efforts take the shape of collective action, joint-coordination and common strategy, including sharing and diffusing best practice models and technical know-how in areas such as transportation, energy and waste infrastructures, and retrofitting projects. These various initiatives engage with national and international forums, but also develop a parallel global governance architecture that bypasses traditional hierarchical channels and state diplomacy bottlenecks. There have been some clear and measurable successes, including a claimed 10,000 city climate actions among members since 2009 , and a collective commitment to $3 \mathrm{Gt}$ of $\mathrm{CO} 2$ reductions by $2030 .{ }^{32}$ However, there is a big caveat: the $\mathrm{C} 40$ network's goals and activities remain well within the discursive space of neoliberal discourse, framing solutions in the language and philosophy of markets, offering technocratic agendas, partnering with

\footnotetext{
${ }^{29}$ The Economist, "Spreading Their Wings : Plans for a 'Northern Powerhouse' Could Transform English Politics," June 6th 2015

${ }^{30}$ Ibid., 238-24.

${ }^{31}$ Justin McGuirk, Radical Cities : Across Latin America in Search of a New Architecture (London: Verso, 2014), 24.

${ }^{32}$ C40 Cities, Climate Action in Mega-Cities 3.0, Dec 2015.

See also http://www.c40.org/blog_posts/from-copenhagen-to-paris-cities-and-mayors-areleading-the-way-on-climate-action
} 
private foundations and multi-national corporations. The $\mathrm{C} 40$ is a prime example of the liberal inflection of the emerging global governance regime.

Some cities have also been generating new forms of security governance. Cities are on the front line of many new security threats, as the transnational networks of value that they house have become potential targets and points of structural vulnerability. We might find the leading edge of this trend in New York City, where, in the post- September 11th 2001 era, the municipal administration has responded to the perceived inability of the state to protect it by developing its own institutional capacities for counter-terrorism. Scholars have noted a gradual militarisation of the New York Police Department, as well as its participation in sophisticated transnational intelligence gathering networks in partnership with other municipal authorities around the world. ${ }^{33}$

And global cities have long been at the core of economic governance - finding their initial raison d'etre as command and control nodes in the construction of a global scale market economy. Under globalisation, a seemingly paradoxical trend of the new economy was making itself clearer during the 1990s: the increasing spatial dispersion of economic activity around the world, as manufacturing relocated to areas of low cost labour, while, at the same time, the global economy became ever-more integrated. Saskia Sassen's seminal theory of the global city provided an explanation for this double movement of dispersal and integration: that the advent of the new international division of labour, the rise of the new organisational form of the multi-national corporation, and the emergence of digital networks and new working practices, have created a need for a new form of strategic command and control in the global economy. The technologically enabled decentralisation of the economy undercuts the traditional controlling and organising function of the state in economic life. At the same time it opens up both a space and a need for new forms of global economic governance. This strategic function has been fulfilled first and foremost by global cities, and the incredible concentration of knowledge, wealth and power that crystalise at their cores.

Although the early global cities literature focussed upon their economic functions, Sassen has also begun to draw out some of the important social implications of the distinctive political economy of the global city form. These include the forms of polarisation and inclusion/exclusion in global cities that the intervening years have only made increasingly obvious. Sassen also relates how new modes of private governance and new forms of private authority have grown up to facilitate the functioning of these global networks, as states have sought to denationalise and marketise formerly public forms of authority. ${ }^{34}$ This hybrid form of public/private governance, as we have seen, is at the core of contemporary global governance strategies.

A unifying factor in governance projects across the political, security and economic domains is that cities and their populations are key players in globalisation. Global cities have generated astonishing levels of growth and economic power, an unprecedented concentration of people and wealth, and have the most advanced technological infrastructures available on the planet. They have scale that stretches across traditional state boundaries, and vast populations that place the traditional understanding of what international politics is into question. Although they may generate many of the most pressing political problems of the day (generating most greenhouse gas emissions, for example), cities represent an immense creative resource to generate solutions to such problems. It is widely recognised now that new ways of urban living must be at the heart of any sustainable solution to climate change. Cities are beginning to act as important 'norm-entrepreneurs' in setting global agendas. A global

\footnotetext{
${ }^{33}$ Kristin Ljungkvist, The Global City 2.0 : An International Political Actor. Beyond Economism? (Uppsala University, 2015).

${ }^{34}$ Saskia Sassen, Territory, Authority, Rights : From Medieval to Global Assemblages (Princeton: Princeton University Press, 2006), 192.
} 
network of thousands of linked cities affords a vast reservoir of human capital and creativity that will develop in unexpected directions.

However, there are clear limits to these early forays into global governance - and these limits speak directly to the question of whether global cities emerge from the failure and impeding irrelevance of states or from their evolution and adaptation. The new autonomy and capabilities of cities do not replace or challenge the agency of states: they are both enabled by and constrained by the power of states and the state-system. Global Cities rehouse existing capabilities and capacities built up in the era of the national-state. In this sense, the empowerment of cities is a product of state rescaling strategies. ${ }^{35}$ Global cities have not emerged from a vacuum - the underlying structure of international society that gave rise to them continues to shape their development and their possibilities.

\section{Geopolitical Roots of the Global City}

We must now push beyond simply noting such developments in global governance to analyse their causal drivers. Only by identifying the specific characteristics of the iteration of international society behind the devolution, decentralisation and augmentation of governance capacities and capabilities are we able to fully understand the implications of global cities for global politics. As I have outlined, these developments in global governance describe a contemporary shift from an international political order rooted in the society of states, to a more diffuse form of global order, which relies upon the interaction of a variety of non-state actors operating at different scales. It is this nascent form of global order that provides global cities with their conditions of possibility, allowing them to become key nodal points in global networks, key sites of systemic contention and contradiction, and actors within the politics of global governance. My central thesis is that global cities have become an integral element of the project of leading states to create, and to secure, a form of decentralised, self-organising market society. This section identifies some of the complex interacting causal drivers of this shift. By assessing the origins of these developments we can gain greater insight into their political implications.

The explanation for the transformation of both urban form and international order may be found in the confluence of a number of factors in the mid to late-twentieth century. These include: the rise of the United States to a hegemonic position; its central role in uniting the liberal capitalist world during the Cold War; its defeat of the Soviet Union and subsequent position of unipolarity. This geopolitical configuration of the international system then interacted with the separate dynamics of crisis induced restructuring of the capitalist world economy in the 1970s, and the rejection of Keynesian embedded liberalism in favour of a monetarist and neoliberal political and economic philosophy. The collapse of the Soviet Union, together with the rejection of Keynesian state management, points us towards another important dimension of this conjuncture: the ideological embrace of decentralisation, long advocated by neoliberal thinkers, as a response to the general crisis of statist forms of social organisation. Additionally, we must also consider the shift in the normative basis of international society outlined earlier: to one of increasingly complex interdependence and cooperation via a deepening of international regimes and institutions aimed at regulating common problems. There has been a quantum leap in the complexity of the technical transnational issues to which international society needs to respond: The response of states has been to embrace the (decidedly questionable) power of the market to solve issues of collective action. Finally, the developmental trajectory of digital information and communications technologies has interacted with these other dimensions in complex ways to empower actors, releasing them from traditional hierarchies, connecting them together in

\footnotetext{
${ }^{35}$ Neil Brenner, New State Spaces : Urban Governance and the Rescaling of Statehood (Oxford: Oxford University Press, 2004).
} 
transnational networks, allowing them to process ever-greater quantities of information. In the following paragraphs I discuss each of these interconnected drivers in turn.

\section{US Hegemony}

It often missed by global city scholars that the type of liberal inflected transnationalism that global cities embody only fully flourished in the American unipolar moment following victory in the Cold War. This period of accelerated global city formation, analysed so effectively by Sassen, must have a power political foundation. It has been the hegemonic power of the United States, and its ability to underwrite and extend the principles of global liberalism, that provided the necessary historical conditions of possibility for global cities to emerge as actors. Global cities operate within the organisational space created by US unipolarity. It is no accident that the other two global cities accompanying New York in Sassen's triumvirate are London and Tokyo, embedded within key allied states.

It is, then, no coincidence that such values begin to reshape both urban morphology and the normative structure of international society in the period of US unipolarity. It should be marked that the embrace of decentralised forms of global governance does not mean that forms of hierarchy have ceased to exist. ${ }^{36}$ As Hurrell argues, American geopolitical dominance is 'the essential power political pivot of the expansion of global liberalism', adding that "whatever view one takes as to the extant character of this US global order, it is evidently the case that the development of liberal solidarism in the 1990s built on this inherited institutional core'. ${ }^{37}$ It remains unclear how far we can distinguish, in the features of contemporary political order, between an anarchical international society characterised by increasingly shared values of global liberalism, and the hierarchical reality of the preponderance of US power. John Ikenberry has effectively shown how the US co-opted other powers into a loosely rule-based liberal hegemonic system, in which it provided international public goods and enforced global security. ${ }^{38}$ Connecting the rise of global cities to the extension of liberal order requires also that we connect their rise to the distribution of power that has allowed the US 'liberal leviathan' to shape the international environment in ways that reflect its core political philosophies.

The ability of US power to continue to underpin this form of political order remains one of the most important open questions of twenty-first century international politics, and it will also be crucial to the continued existence of the global city form. The liberal ascendency has been with us since the end of World War Two, and has accelerated since the fall of the Soviet Union. It will not be derailed easily - too many players have an important stake in its survival, and no attractive alternative system has presented itself. Previously the route to overthrowing a particular international order lay in great power hegemonic war. With the stabilising influence of nuclear weapons and the seemingly unbridgeable gap between US military power and the rest, this no longer seems to be a likely path for the future of international order. The probability is that an international order with liberal market characteristics will endure in some form or another, even in the light of US relative decline, and in the teeth of the rising power of illiberal heavyweights such as China and Russia. This system is now firmly enough established for some to suggest that it could out-last US hegemony. ${ }^{39}$ This is important, because the possibility for open, global cities will remain symbiotic with some kind of liberal international order.

\footnotetext{
${ }^{36}$ David Lake, Hierarchy in International Relations (London: Cornell University Press, 2009).

${ }^{37}$ Hurrell, On Global Order, 75-86

${ }^{38}$ John Ikenberry, Liberal Leviathan : The Origins, Crisis, and Transformation of the American World Order (Princeton, N.J.; Woodstock: Princeton University Press, 2011).

39 John Agnew, and Stuart Corbridge, Mastering Space : Hegemony, Territory and International Political Economy (London: Routledge, 1995); Michael Hardt, and Antonio Negri, Empire (Cambridge, Mass. ; London: Harvard University Press, 2000).
} 
In addition to linking the rise of the global city to US-led liberal order, it should also be viewed as part of the response to a succession of crises of statist (that form of political life in which states have substantial centralised control over political and economic activities) forms of international political economy over the past two centuries. The emergence of global cities may be read as a strategic response to the tensions that have emerged from the two conflicting master logics of modern life: the 'incongruent spaces' of a political structure built upon sovereign territoriality and the fundamentally transnational capitalist economic structure that grew up within it. ${ }^{40}$ Earlier responses to the difficulties that statist modes had with negotiating the mismatch between economic and political structures played a central role in the major political and social upheavals of the nineteenth and twentieth centuries, as different variants of the state emerged and transformed in a series that included imperialist, socialist, national socialist and social democratic welfare states. ${ }^{41}$ In each case states were responding to the limitations of statist politics by unleashing forces of transformation that reshaped the state itself. The crisis of the western social democratic national state, as well as the eventual collapse of the Soviet Union, should be set in a long series of crises of statism. The global city emerges as part of the latest attempt to mediate this scalar gap.

The victory of a specific 'neoliberal' political philosophy within the US political system over the course of the last four decades has formed the bedrock for a transformation of both states and markets. Between 1945-70, to use Karl Polanyi's terminology, market capitalism was embedded within a set of institutions that tamed the social dislocations that it inevitably brought in its wake. The Bretton Woods system set a firm framework of rules and institutions for international commercial and financial transactions, underpinned by US hegemony and the dollar. However, in 1971, President Nixon, responding to a combination of factors (the cost of the Cold War, particularly the expense of the war in Vietnam, the 'oil shocks' resulting from crisis in the Middle East, and the inexorable rise in wages, saturation of domestic markets, and crisis of capitalist profitability), broke the convertibility of the dollar into gold. In the reconstituted system, the ideas and principles of neoliberalism, which had remained out of favour for decades, were adopted. Its central principles were a commitment to free markets, minimal state involvement in economic affairs, free movement of capital, and the extension of the competitive dynamics of the market to most aspects of social life. The dollar to gold peg was replaced by a system of floating exchange rates, and the dollar now became a reserve currency. In place of the tightly regulated capital controls of the post-war period came the evolution of the global financial markets, as capital was freed to move internationally to seek the best returns. This in turn led to the great rise of the transnational corporation, and the growth of foreign direct investment, as firms sought new opportunities beyond their saturated domestic markets. The result was a new spatial order, an integrated global economy, in which cities would be freed to take on a pivotal role. The allocation of capital and the mobility and speed with which finance flowed around the globe was greatly augmented by the emergence of the new information technologies, and the advent of computerised trading exchanges and stock markets in the 1980s.

The project to create a global market society, in which the state would be reduced and transformed into a form of market state, and in which an embrace of decentralisation would call forth the functional requirement of the global city, has hollowed out the social democratic Keynesian welfare state, most likely irreparably. The resultant market state is underpinned by a very different rationale to the fading nation-state it is replacing: its function is no longer to

\footnotetext{
${ }^{40}$ Hannes Lacher, Beyond Globalization : Capitalism, Territoriality and the International Relations of Modernity (Abingdon: Routledge, 2006); Brenner, New State Spaces

${ }^{41}$ Henri Lefebvre, Neil Brenner, and Stuart Elden, State, Space, World : Selected Essays (Minneapolis: University of Minnesota Press, 2009).
} 
maximise the welfare of its citizens, but their opportunities. Rather than utilising resources directly, this form of state redistributes resources into private hands. It stresses meritocracy as a justification for hierarchical and unequal social relations. The conception of human selfhood here is competitive and individualistic. This is the risk society of reflexive latemodernity described by Ulrich Beck,,where the older strategies that nation-states used to protect their citizens from the economic and political hazards beyond its borders is at an end. ${ }^{42}$ Furthermore, the privatisation of key national assets and infrastructures has fractured the integrated homogenous space that had been a result of over two centuries of nation building. Philip Bobbitt suggests that the change in the constitutional basis of the state represented by the market state also brings forth warped forms in its own image: just as the market state takes on a networked, decentralised and outsourced form, so too do social movements, and criminal and terrorist networks. ${ }^{43}$ The resultant extended transnational infrastructures and networks of valued flows draw out new forms of state strategy; as we shall go on to see.

The political response by leading states to the linked crises of statism and embedded liberalism has, then, involved a recalibration of the relationship between state, market and civil society, creating a form of order that, building on Polanyi, we might call a global market society. ${ }^{44}$ As we have seen, within global governance architectures market exchange is increasingly seen as the solution to problems of collective action. That the market has come to occupy such a pre-eminent position in the institutions of international society may be viewed as the internationalisation of a US inflected culture of political economy. As Panitch and Gindin have made clear, the US state was absolutely essential to the making of global capitalism. Against what they consider to be a tendency to posit a false dichotomy between states and markets, they argue that the US state has been central to planning and implementing the emergence of global capitalism in the twentieth century; expanding a vision of market civilization to the global scale, and defending those components needed for it to function - property rights, currency stability, periodic crisis containment - as well as defending it from geopolitical challenges, as in the Cold War struggle against the Soviet Union. Indeed, the US has also played a key role in restructuring other states to conform to the state forms required for a globalised capitalism: whether this be in the post World War reconstruction of its former enemies, Germany and Japan, or through the structural power of international institutions that have demanded 'structural adjustments' to the domestic political economies of states seeking entry into the global economy. ${ }^{45}$

\section{Technological Change}

This specific culture of political economy has also found its expression in the shape of technological developments that underpin new global practices. As Castells and others have argued, technology develops within a particular social structure, is imbued with particular social values and aims, and evolves in response to signals given by particular economic frameworks. ${ }^{46}$ Technology embodies society, and society shapes technological development:

\footnotetext{
${ }^{42}$ Ulrich Beck, and Mark Ritter, Risk Society : Towards a New Modernity (London: Sage Publications, 1992).

${ }^{43}$ Philip Bobbitt, The Shield of Achilles : War, Peace and the Course of History (London: Allen Lane, 2002).

${ }^{44}$ Karl Polanyi, The Great Transformation : The Political and Economic Origins of Our Time (Boston, MA: Beacon Press, 1957).

${ }^{45}$ Sam Gindin, and Leo Panitch, The Making of Global Capitalism : The Political Economy of American Empire (London; Brooklyn, NY: Verso, 2013).

${ }^{46}$ Manuel Castells, The Rise of the Network Society (Cambridge, MA: Blackwell Publishers, 1996); Donald MacKenzie, and Judy Wajcman, The Social Shaping of Technology (Buckingham ; Philadelphia: Open University Press, 1999).
} 
'technology is society made durable' ${ }^{47}$ This insight is crucial when we come to consider how cultural and social norms and forms of political order have shaped the material infrastructure for the new transnational socio-technical networks formed by global cities. Such transnational networks rest upon a culture that embraces decentralisation, self-organising complexity, and multi-nodal pluralism. Castells has further drawn the link between these technological forms and the liberal values emerging in the context of dominance of US politics and culture.

It is, then, the profound developments in digital information and communications technologies in the last quarter of the twentieth century that give the global city characteristics that are different from earlier cities. Global cities house the key material and social components of a transnational system of financial innovation and exchange. This infrastructure is selectively sited, maintained and upgraded within particular global cities. The emergence of networked forms of digital information and communications technologies are, as David Harvey has argued, inseparable from the success of the neoliberal project, where the decentralized 'global market place' is only made visible by the ability of technology to record, store and analyse. ${ }^{48}$ The development of these technological infrastructures has begun to alter the relative balance between territory, scale, place and networks. ${ }^{49}$ The splintering and commodification of national space inherent in the ideals and practices of neoliberalism - in particular, privatisation - has created a set of new spatial forms that jump scales and tie various fragments of global space together in novel ways. The network becomes a key organisational form.. What global city networks represent is nothing less than the material infrastructure for sustaining a global market society.

The most advanced forms of information and communications technology infrastructures are, then, part of the fabric of the global city, and there is clear potential to use this technology to generate efficient solutions to a variety of problems. Promising developments coalesce around the marrying of new technologies with urban management. There is a growing emphasis on Smart Cities - the application of a combination of information communications technologies and 'big data' to urban management. These technologies promise an enhanced understanding of the patterns of urban life drawn by vast populations. Such developments augur a future in which greater control can be exercised over urban processes. Because the technologies involved draw upon logics of decentralisation, dispersal and bottom-up dynamics, they point away from the older model of statist top-down hierarchical control. In this sense, they fit nicely with the forms of networked authority that cities have always embodied, and highlight the increasingly problematic nature of state sovereignty. ${ }^{50}$

The complexity of transnational challenges at the global scale requires this processing power. The demands of technical knowledge within this complex system are increasingly beyond the competence of any one state, or collection of states. Hybridity in global governance provides the functionality to tackle this complexity. The specialized technical knowledge developed by private actors has made their incorporation into the task of producing global public goods essential. In this sense the emergence of global governance may be viewed as a functional adaptation to the complexity of transnational political life. ${ }^{51}$ It is, however, important not to take this functionalist logic too far. For, as we have seen, there is a large degree of historical

\footnotetext{
${ }^{47}$ Bruno Latour, "Technology is Society Made Durable" Sociological Review Monograph 38 (1991): 103-132.

${ }^{48}$ David Harvey, A Brief History of Neoliberalism (Oxford ; New York: Oxford University Press, 2005), 2-4

${ }^{49}$ Bob Jessop, Neil Brenner, and Jones, "Theorizing Sociospatial Relations," Environment and Planning D, 26, no. 3 (2008): 389-401.

${ }^{50}$ Warren Magnusson, Politics of Urbanism : Seeing like a City (New York : Routledge, 2011).

${ }^{51}$ Magali Delmas, and Oran Young, Governance for the Environment : New Perspectives (New York: Cambridge University Press, 2009).
} 
contingency in the emergence of hybrid global governance. The global city is ultimately a contingent phenomenon; a product of the historical confluence of power, ideas, social practices and technologies; driven by the limits of previous models of political economy, and also by weaknesses in the structure of international society, as it seeks to adapt to a world of complex interdependence.

\section{Cities in a Global Order: Reopening Pandora's Box?}

Having argued that global cities emerge in response to multiple interlacing historical drivers that have generated a historically specific form of global order, the final section of this article will consider some of the implications of these developments for contemporary global politics. I want to highlight three interlinked consequences of this form of global order. Because state form and city form are linked, in parallel with the emergence of global cities new forms of market state have developed that point towards a shift in the nature of modern sovereignty. New security practices are visible that bring into question traditional assumptions about territoriality and bordering. And, as a result, the logics of the wider modern international order have been fractured, with potentially destabilizing results.

At its heart the emergence of the global city, and the open question of how it fits into contemporary global order, is but one symptom of a crisis in the ordering principles of international political life. Pushing beyond the pluralist form of international order, towards a form of liberal global order, has begun to produce a deformation in traditional understandings of territory and sovereignty. The compact between the market state and the global city may have offered a decentralising solution to the crises of statism, but it also raises a variety of questions about the potentially emergent and unexpected logics that may arise as a result. The creation of such new spatial forms as global cities and their networks is a symptom of 'the increasingly puzzling character of the problem of sovereignty'. ${ }^{52}$ As the market state moves to unravel the previous spatial mode, privatising, parcelling and commodifying its formerly homogenous national space - the most valued fragments of which are reconnected at the transnational scale in novel formations - new fractures and fault-lines appear within the structures of modern international order. As the state works to pursue strategies that reshape its territory, it places great stress on those supports that have given it its modern form. The emergence of the novel governance assemblage of which global cities are a key component brings into doubt the continued viability and integrity of the modern spatial settlement, and suggests an uncertain future in which this settlement must now be systematically renegotiated at every scale.

The modern concept of sovereignty has typically produced sharply demarcated boundaries clear insides and outsides - that now appear to be weakening. But modern sovereignty is not just a historically particular production of space. As Rob Walker has tried to show throughout his work, the 'international' is a complex philosophical edifice that, having emerged as a solution to the crises that wracked seventeenth-century Europe, operates as a historically specific response to the problem of generating stable political order. ${ }^{53}$ This has been a remarkably powerful system, and any unravelling of that solution (to which the developments charted here do indeed point) is likely to reopen a host of political and philosophical questions which will need to be solved in new ways. Walker thus seeks to resist the notion that we can move in any simple linear sense from a politics of the international to a politics of the globe, or of some world beyond the international: any such shift will unleash the forces

\footnotetext{
${ }^{52}$ Rob Walker, After the Globe, before the World (London: Routledge, 2010), 53

${ }^{53}$ Rob Walker, Inside/Outside : International Relations as Political Theory (Cambridge: Cambridge University Press, 1993).
} 
that the modern international system evolved to tame. Rather than offering a way out of the problems generated by the system of territorial states, the moves towards global order that we have charted here risk opening a Pandora's box of virulent political riddles. Such a deformation of traditional conceptions of sovereignty and territory threatens to reawaken the political issues that the modern political settlement had worked to tame within state territorial boundaries. The opening of the territorial container that the scale-hopping global city represents threatens to once again unleash the powerful forces that it was built to contain.

For example, the rescaled market state has a very different raison d'être to the nation-state it has replaced: its objects of sovereign decision now extend beyond the traditional homeland territory. This shift is exemplified by an evolution in security discourses and practices. The security practices of leading states exhibit a notable shift in focus in recent decades: from securing the traditional territorial border to new practices aimed at securing the new flows of value, which run primarily through the world's urban networks. Stephen Graham has shown how US defence planners have been developing a strategy of 'forward defence', which involves pushing the concept of the border outwards to tackle threats before they reach the US mainland - as in the Container Security Initiative that seeks to secure the global network of seaports. ${ }^{54} \mathrm{But}$, at the same time, the valued spaces of global flows on which the US depends (electronic finance, Internet communications, trade and transport) must also be protected. The US Department of Homeland Security now talks of creating a 'global security envelope'. There have been attempts to 'reengineer global finance, communication, airline and port systems to achieve a kind of ubiquitous border, a 'global homeland' which follows the infrastructural architectures of a global network of cities and economic enclaves rather than the territorial limits demarcating nation-states' ${ }^{55}$ Some have argued that these tensions may signal the eventual replacement of the national security apparatus with a decentralised transnational security system combining public authority, private actors and individuals: yet another governance hybrid. ${ }^{56}$ One way to characterise such a system in formation is as a transnational security assemblage - as Abrahamson and Williams do in their study of the complex transnational security formation emerging in Africa of state governments and militaries, private security firms and individuals. ${ }^{57}$

Part of the explanation for this shift lies in the emergence of the market state and the political philosophy that underpins it. Nation-states are no longer able to shield their citizens effectively from global economic flows, just as they are increasingly unable to guarantee the security of the national citizen in the face of transnational risks such as climate change, pandemics and international terrorism, or even to guarantee the national border in a world of nuclear weapons. The very raison d'etre of the nation-state rested upon such guarantees: securing the national border, enforcing civil peace through the rule of law, guaranteeing economic stability, welfare and employment. ${ }^{58}$ No longer able to fulfil its constitutional promise of securing the welfare and security of its citizens, this pillar of legitimacy has been removed (exemplified by the neoliberal roll back of welfare commitments and nationally integrated infrastructures, for example) to be replaced by a very different promise: that of securing access and opportunity in a global market society.

\footnotetext{
${ }^{54}$ Stephen Graham, Cities under Siege : The New Military Urbanism (London: Verso, 2010), 135

${ }^{55}$ Ibid., 77

${ }^{56}$ John Robb, Brave New War : The Next Stage of Terrorism and the End of Globalization (Hoboken, N.J.: John Wiley \& Sons, 2007).

${ }^{57}$ Rita Abrahamsen, and Michael C. Williams, "Security Beyond the State: Global Security Assemblages in International Politics," International Political Sociology, 3, no. 1 (2009): 117.

${ }^{58}$ Bobbitt, The Shield of Achilles, 228.
} 
The post-Cold War privatisation of warfare contributes to this instability. As a result of the liberal marketisation of the weapons industry, unprecedented quantities of weapons and sources of finance flow around the system. ${ }^{59}$ Security threats are, as a result, much more diffuse and decentred. Here, again, the rise to prominence of the global city is a key part of this shift in the security landscape. Cities have become the primary locus of contemporary violence, whether it be the Islamist inspired terrorist attacks on cities such as New York, London, Paris, Madrid or Mumbai, or the urbanicide of the 'war on terror' in the cities of Iraq. ${ }^{60}$ Just as cities become the key nodal sites and critical infrastructure of a globalised political economy, so too do they offer the most tempting targets.

Indeed, the development in recent decades of what Graham has called the 'new military urbanism' (a trend that it is worth noting was in evidence since before September 11th, 2001, but greatly exacerbated by those events) highlights how the city has become central to the changing architecture of international security. Novel security practices in evidence in contemporary urban spaces are a reflection of the wider structural shift in the nature of international society. Traditional security lenses are an inadequate guide to the ways in which cities and urbanisation are at the heart of novel and unfolding territorial forms of control, inequality and insecurity. As we saw earlier in the discussion of the security dimension of global city governance, urban life is increasingly subject to a creeping militarisation, and a blurring of the traditional lines between civilian policing and military force.

The emergence of novel configurations of transnational space has made it far more difficult to 'draw the line' between the inside and the outside of the state, and to maintain the distinction between traditional military operations and domestic policing. As transnational flows and circuits (commodity chains, logistics networks, urban transnational infrastructures) have become the lifeblood of powerful market states, so these states must develop new strategies to secure them. As global cities are the crucial command and control nodes for the deployment and switching of global capital throughout the developed and developing worlds, securing such transnational urban spaces becomes crucial to such a strategy. Global city networks are thus implicated in the operations of a system of transnational neoliberal capitalism; they form its material conduits and exoskeleton, and are increasingly the medium through which such a system is secured. The complex challenge for such a form of political order has become how to achieve such security, whilst also allowing for the embrace of the hyper-mobility that characterises the neoliberal global political economy. The answer alighted upon thus far seems to be a market liberalism underpinned by increasing authoritarianism and militarism, directed both at securing valued spaces abroad and at targeting problematic citizens at home. This is a development that would not have surprised Karl Polanyi, who saw how the nineteenth-century attempt to generate a market society brought its own authoritarian impulses. As the polarisation of wealth generated by market society finds its purest spatial expression in global city morphology, cities become the focus of social control. There is a notable convergence between techniques and practices of policing, intelligence gathering and military tactics:

'states are becoming internationally organised systems geared towards trying to separate people and circulations deemed risky or malign from those deemed risk-free or worthy of protection... resulting in a blurring between international borders and urban/local borders. Indeed, the two increasingly seem to meld, to constitute a 'multiplicity of control points' that become distributed along key lines of circulation and key geographies of wealth and power..., ${ }^{61}$

\footnotetext{
${ }^{59}$ Mary Kaldor, New and Old Wars : Organized Violence in a Global Era (Cambridge: Polity Press, 1999).

${ }^{60}$ Martin Coward, Urbicide : The Politics of Urban Destruction (London: Routledge, 2009).

${ }^{61}$ Graham, Cities Under Siege, 89
} 
The political geographer John Agnew has urged us to see such developments as a form of territoriality: the politically strategic use of territory 'by way of defining market spaces geographically, organising military commands, and inventing new forms of supra-national authority'. ${ }^{2}$

What we see here is a shift in the nature and location of borders that relates directly to changes in the nature of the state. It is the transnational extension of national interests, in the service of the logics of capital, that seems to be driving the deconstruction and reconstruction of borders, and with them the inside/outside solution alighted upon by modernity. One thrust of the new Critical Border Studies literature is to argue that the dividing line that demarcates and constitutes the state system is somehow shifting - unleashing a whole host of new speculations on the nature of territoriality and sovereignty, the transformative impact of networks and the recasting of centres and peripheries. No longer can we assume that borders appear only at the edges of the territorial state container. Rather, new borders and boundaries are appearing in unexpected places, winding their way across stretches of global space. Much of this spatial deformation has been facilitated by the new network technologies, which have the capacity to generate novel inside/outside configurations, such as global city networks. We have seen the same logic operating at a different scale: on the very fabric of the global city, where gated communities, privatised infrastructural networks and the citedelisation of transportation and central business districts recapitulate the practice of drawing new borders and boundaries deep within the city, and thus deep within and far away from the older border of the national state. The ability of non-state actors to draw borders has become diffused throughout society, as a result of the embrace of multi-level governance. ${ }^{63}$

When order and security become the primary foundations of sovereign legitimacy, and when security threats become diffuse and borders mutate, it is perhaps inevitable that in the pursuit of these goals states will be drawn to ever more authoritarian postures and militarised techniques, as they move secure valued infrastructures. Such developments may easily be read as a form of neo-imperial practice. Graham has argued that the network of global cities forms part of nothing less than a 'transnational imperial infrastructure', bound up with US structural power in the contemporary global order ${ }^{64}$ There is a complex relationship at work here between contemporary and earlier forms of imperial control, as 'imperialist and colonial geographies 'umbilically connect' the metropolitan cores of global city nodes with the developing periphery.

\section{Conclusion}

In this article my method has been to take a concrete phenomenon, the increasingly visible governance activates of cities at the transnational level, and to progressively uncover the drivers that have produced it. These have included the increasing prominence of global governance, its role as part of a decentralised neoliberal strategy of leading states to construct a global market society, the configuration of power in international society that underpins the projection of this strategy, and the history of failure of statist forms of political economy that produced the strategy.

I then went on to tease out some of the implications of these developments. We saw how from these origins a new relationship between the state and the city has emerged, and how traditional conceptions of sovereignty, territoriality and security have been stretched and deformed, as the state seeks to secure the transnational networks of value that run through global cities. Leading states now draw their lifeblood from the transnational flows passing

\footnotetext{
${ }^{62}$ John Agnew, "Still Trapped in Territory?," Geopolitics, 15, no. 4 (2010): 779-784.

${ }^{63}$ Chris Rumford, "Towards a Multiperspectival Study of Borders," Geopolitics, 17, no.4 (2012): 887-902.

${ }^{64}$ Graham, Cities Under Siege, 367
} 
through global city networks, and rely upon the intricate material infrastructures sustaining them. It seems a logical corollary that states will seek to modify their security practices to protect these spaces, extending their reach across selected networks of valued transnational space.

We must be careful, then, not to misread the developments charted here as some simple shift from a form of order based upon the international society of states to a form of order where the state no longer plays a central role, as in some of the more naive globalisation theories, or in Barber's hoped for scenario of 'municipal confederalism'. It is not simple state failure with which we are faced, but, instead, the emergence of a complex configuration of global order in which states now take their place in a meshwork of governance arrangements that includes other sites of authority and influence, perhaps the most important of which is the global city. 